\title{
Characterization by Deep Sequencing of Prunus virus T, a Novel Tepovirus Infecting Prunus Species
}

\author{
Armelle Marais, Chantal Faure, Eldar Mustafayev, Maria Barone, Daniela Alioto, and Thierry Candresse
}

First, second, and sixth authors: INRA and Université de Bordeaux, UMR 1332 BFP, CS20032, 33882 Villenave d'Ornon Cedex, France; third author: Genetic Resource Institute of the Azerbaijan National Academy of Sciences, Az-1106 Baku, Azerbaijan; and fourth and fifth authors: Università degli Studi di Napoli "Federico II", Dipartimento di Agraria, I-80055 Portici, Italy.

Accepted for publication 13 June 2014.

\begin{abstract}
Marais, A., Faure, C., Mustafayev, E., Barone, M., Alioto, D., and Candresse, T. 2015. Characterization by deep sequencing of Prunus virus T, a novel Tepovirus infecting Prunus species. Phytopathology 105:135-140.

Double-stranded RNAs purified from a cherry tree collected in Italy and a plum tree collected in Azerbaijan were submitted to deep sequencing. Contigs showing weak but significant identity with various members of the family Betaflexiviridae were reconstructed. Sequence comparisons led to the conclusion that the viral isolates identified in the analyzed Prunus plants belong to the same viral species. Their genome organization is similar to that of some members of the family Betaflexiviridae, with three overlapping open reading frames (RNA polymerase,

movement protein, and capsid protein). Phylogenetic analyses of the deduced encoded proteins showed a clustering with the sole member of the genus Tepovirus, Potato virus $T$ (PVT). Given these results, the name Prunus virus $\mathrm{T}$ (PrVT) is proposed for the new virus. It should be considered as a new member of the genus Tepovirus, even if the level of nucleotide identity with PVT is borderline with the genus demarcation criteria for the family Betaflexiviridae. A reverse-transcription polymerase chain reaction detection assay was developed and allowed the identification of two other PrVT isolates and an estimate of $1 \%$ prevalence in the large Prunus collection screened. Due to the mixed infection status of all hosts identified to date, it was not possible to correlate the presence of PrVT with specific symptoms.
\end{abstract}

In the past few years, next-generation sequencing (NGS) using various technologies and templates (RNAs, DNA, short interfering RNAs, and double-stranded RNAs [dsRNAs]) has allowed the rapid identification and characterization of a number of novel or known plant viruses $(1,3-9,11-16,19,20,23-26)$. In particular, fruit tree materials have been screened for viral infection by NGS, and divergent isolates of known viruses belonging to the families Betaflexiviridae and Closteroviridae characterized $(7,15)$ as well as new members of the families Alfaflexiviridae and Betaflexiviridae have been detected $(9,14)$. A recent study also revealed the presence of a new rhabdovirus in Japanese persimmon (13).

The family Betaflexiviridae comprises seven genera, Capillovirus, Carlavirus, Citrivirus, Foveavirus, Trichovirus, Vitivirus, and the recently accepted Tepovirus genus, which is typified by its sole member, Potato virus $T$ (PVT) $(2,17)$. The family members are characterized by the numbers of genes and proteins encoded, between three and six depending on the genus, and by the type of movement proteins (MPs) encoded: either a single MP of the "30K" superfamily (Capillovirus, Citrivirus, Trichovirus, Vitivirus, and Tepovirus) or a "triple gene block" (the remaining genera and some unassigned species in the family). The plant host range of the family members is very large, even though each viral species has, in general, been reported only from a few, usually

\section{Corresponding author: A. Marais; E-mail address: amarais@bordeaux.inra.fr}

The sequences reported in this article have been deposited in the GenBank database under the accession numbers KF700262, KF700263, KF805860, and KJ534579.

* The $\boldsymbol{e}$-Xtra logo stands for "electronic extra" and indicates that the online version contains one supplementary table.

http://dx.doi.org/10.1094/PHYTO-04-14-0125-R

This article is in the public domain and not copyrightable. It may be freely reprinted with customary crediting of the source. The American Phytopathological Society, 2015. woody, host plant species, with the exception of carlaviruses, which tend to have herbaceous hosts (2).

In this study, NGS analysis of dsRNAs from cherry and plum trees enabled the assembly of the whole genome of two isolates of the same new viral species. Our findings indicate that the genome of this virus is sufficiently distinct from that of PVT (Tepovirus, Betaflexiviridae), the most closely related virus, to propose its classification as a separate species in the genus Tepovirus. The name of Prunus virus T (PrVT) is proposed.

\section{MATERIALS AND METHODS}

Plant material and virus isolates. The sweet cherry tree $\mathrm{C} 21$ (Prunus avium 'Tardiva di Roccamonfina') was obtained from a germplasm collection of old cherry varieties in the Campania region of Italy. The plum tree (P. domestica) 'Aze239' was collected in the botanical garden of the Nakhchivan Natural Resources Institute in Azerbaijan. Various Prunus sources ( $P$. domestica, $P$. avium, $P$. cerasus, $P$. cerasifera, $P$. mume, $P$. salicina, $P$. persica, $P$. armeniaca, $P$. dasycarpa, $P$. sibirica, and Prunus sp.) were collected during several surveys in Azerbaijan, China, Iran, Italy, Czech Republic, and France. Samples of Pyrus communis used as negative controls were also collected in Italy.

Determination of the full-length genomic sequences. dsRNA were purified from leaves of Prunus avium C21 and of $P$. domestica Aze239, reverse-transcribed, random amplified, and submitted for 454 pyrosequencing according to the strategy described by Candresse et al. (7). The manipulations and analyses of 454 sequencing data were performed as previously reported (7) using the CLC Genomics Workbench 5.5 (http://www.clcbio.com). After demultiplexing, the reads were assembled into contigs which were annotated by Blastx and Blastn comparison with GenBank nonredundant nucleotide database, using a $10^{-3}$ e-value cut-off. Mapping of contigs on the genome of PVT used as a reference allowed the construction of scaffolds linking and order- 
ing the contigs obtained for each viral isolate. Primers were then designed to amplify PCR products spanning the gaps between the various contigs. The same strategy was also used for a few genomic regions with low coverage and for which sequence confirmation was sought. The sequences of the primers used, as well as their annealing temperature, are presented in Supplementary Table 1 . The $5^{\prime}$ ends of the genomes of the two viruses were determined using the $5^{\prime}$ random amplification of cDNA fragments (RACE) strategy and reverse internal primers designed from the contigs. Amplifications were carried out following the recommendations of the RACE kit supplier (Takara Bio Europe/Clontech, Saint-Germain-en-Laye, France). In the case of Aze239 virus, a nested polymerase chain reaction (PCR) using the nested primer supplied by the kit and the N-RaceAze239 primer was used to amplify the $5^{\prime}$ end of the genome. The $3^{\prime}$ genomic regions were amplified using forward internal primers designed from the contigs and the LD-prime primer in longdistance PCR amplification reactions, following the protocol described in Youssef et al. (27). All amplified fragments were submitted to Sanger sequencing (GATC Biotech, Mulhouse, France) either directly or after cloning in the pGEM-T Easy vector (Promega, Charbonnières-Les Bains, France).

Sequence and phylogenetic analyses. Multiple alignments of nucleotide sequences or of deduced amino acid sequences were performed using the ClustalW program (22) implemented in Mega 5.2 (21). Average pairwise distances were computed using Mega 5.2. Phylogenetic reconstructions were performed using the neighbor-joining technique with strict nucleotide or amino acid distances and randomized bootstrapping evaluation of branching validity using Mega 5.2.

Total nucleic acid extraction and detection of the new virus by RT-PCR. Extraction of total nucleic acids (TNAs) was performed according to procedure 2, described by Foissac et al. (10). The virus was detected by a two-step reverse-transcription (RT)-PCR. TNA $(5 \mu \mathrm{l})$ was submitted to a reverse transcription using a mixture of $\mathrm{dN}_{6}$ and $\mathrm{dT}_{18}$ as reverse primers and the RevertAid Reverse Transcriptase following the recommendations of the manufacturer (Thermo Scientific, Illkirch, France). The

TABLE 1. Lengths and Blastx analysis results for 454 pyrosequencing de novo contigs from the cherry $\mathrm{C} 21$ and plum Aze239 samples with detectable homology to Betaflexiviridae members

\begin{tabular}{lclcc}
\hline $\begin{array}{l}\text { Sample, } \\
\text { contig }\end{array}$ & $\begin{array}{c}\text { Contig } \\
\text { length (bp) }\end{array}$ & \multicolumn{1}{c}{ Blastx virus $^{\mathrm{a}}$} & $\begin{array}{c}\text { Blastx } \\
\text { e-value }\end{array}$ & $\begin{array}{c}\text { Identity } \\
(\%)\end{array}$ \\
\hline C21 & & & & \\
2 & 1,368 & MV2 (AAX07259) & $8.14 \mathrm{E}-86$ & 50 \\
4 & 1,338 & PVT (BAM16482) & $7.07 \mathrm{E}-68$ & 35 \\
39 & 667 & BanMMV (NP112029) & $4.37 \mathrm{E}-11$ & 37 \\
58 & 427 & ScVA (AEN25487) & $2.75 \mathrm{E}-16$ & 48 \\
Aze239 & & & & \\
6 & 606 & HpLV (NP066258) & $1.41 \mathrm{E}-07$ & 39 \\
17 & 271 & PVT (BAM16482) & $3.81 \mathrm{E}-05$ & 44 \\
78 & 646 & GVB (ABH05389) & $6.78 \mathrm{E}-61$ & 57 \\
79 & 325 & PVT (BAM16482) & $4.86 \mathrm{E}-14$ & 49 \\
94 & 256 & PVT (BAM16482) & $5.73 \mathrm{E}-12$ & 63 \\
118 & 236 & GVA (ABL14358) & $4.16 \mathrm{E}-50$ & 64 \\
\hline
\end{tabular}

a Acronyms used: MV2 = Mint virus 2, PVT = Potato virus $T$, BanMMV = Banana mild mosaic virus, $\mathrm{ScVA}=$ Scaveola virus $A, \mathrm{HpLV}=$ Hop latent virus, $\mathrm{GVB}=$ Grapevine virus $B$, and $\mathrm{GVA}=$ Grapevine virus $A$.
cDNA $(5 \mu \mathrm{l})$ was then amplified using $1 \mu \mathrm{M}$ each of the Tep-1F (5' CCIGGIYTIGGIGGIMGICAYGGICARATG $3^{\prime}$ ) and Tep-1R (5' ACTTTATTAAGTTAAAGCTAAGCCGCC $3^{\prime}$ ) primers in a $50-\mu \mathrm{l}$ reaction volume containing $10 \mathrm{mM}$ Tris- $\mathrm{HCl}(\mathrm{pH} \mathrm{8.8)}$, $1.5 \mathrm{mM} \mathrm{MgCl}_{2}, 50 \mathrm{mM} \mathrm{KCl}, 0.1 \%$ Triton X-100, $250 \mathrm{mM}$ dNTPs, and one unit of DyNAzyme II DNA polymerase (Finnzymes; Thermo Scientific). After a first step of denaturation $\left(5 \mathrm{~min}\right.$ at $\left.95^{\circ} \mathrm{C}\right), 40$ cycles were applied, each of $30 \mathrm{~s}$ at $95^{\circ} \mathrm{C}$, $30 \mathrm{~s}$ at $52^{\circ} \mathrm{C}$, and $1 \mathrm{~min}$ at $72^{\circ} \mathrm{C}$. The amplified fragments were visualized by agarose gel electrophoresis and their nucleotide sequence determined by Sanger sequencing (GATC Biotech) with or without a cloning step in pGEM-T (Promega).

\section{RESULTS}

Complete sequence determination by pyrosequencing. After demultiplexing, 1,415 (C21 cherry) and 6,553 (Aze239 plum) reads were obtained. Quality trimming resulted in a total of 1,151 reads with a length of $>60$ nucleotides (nt) (average length $257 \mathrm{nt}$ ) and 6,132 reads (average length $152 \mathrm{nt}$ ), respectively. De novo assembly of the $\mathrm{C} 21$ cherry reads resulted in a total of 104 contigs of $>100 \mathrm{nt}$, integrating $71.4 \%$ of the reads, and 329 singletons. In the case of the Aze239 plum, 212 contigs (48.7\% of reads) were obtained and 3,140 singletons. All contigs were annotated by Blastn and Blastx analysis against the GenBank database and using a conservative $10^{-3}$ e-value cut-off. For each sample, contigs with high levels of identity with known viruses were identified. For the cherry $\mathrm{C} 21$ sample, this included 14 contigs of Little cherry virus 1 (LChV1), 11 contigs of Apple chlorotic leaf spot virus (ACLSV), and 7 contigs of Prune dwarf virus (PDV). For the Aze239 plum sample, this included 14 contigs of Apricot pseudo chlorotic leaf spot virus (APCLSV), 14 contigs of Cherry virus $A$ (CVA), and 7 contigs of ACLSV. In addition, in each plant, some additional contigs were identified with distant homology to members of the family Betaflexiviridae (Table 1). In the case of the $\mathrm{C} 21$ cherry, the four contigs thus identified have a cumulated length of $3.8 \mathrm{~kb}$ and represent $21.9 \%$ (252 reads) of total reads. The corresponding values for the six contigs derived from the Aze239 plum sample are $2.34 \mathrm{~kb}$ for $1.5 \%$ (94 reads) of total reads. For each viral source, the contigs were further manually assembled by mapping against a reference Betaflexiviridae genome, thus allowing creation of a tentative scaffold. The C21 scaffold thus obtained spanned the genome to the $3^{\prime}$ end, missing only $\approx 600$ nucleotides at the $5^{\prime}$ end and a large internal gap. For Aze239, the scaffold obtained missed both the $5^{\prime}$ end $3^{\prime}$ genome ends and contained, in addition, two internal gaps. Completion and polishing of both sequences were performed using TNA extract from leaves of the two plants, and sequencing of PCRgenerated fragments using primers defined from the pyrosequencing data. No differences were observed between the initial genome assembly and the regions resequenced using confirmatory PCR products. The complete genome sequences were finally assembled for both agents and were deposited in the GenBank database under accession numbers KF700262 and KF700263 (Table 2). These genomes share an overall $74 \%$ nucleotide identity, and Blastx analysis indicated that the viruses with the closest affinities are in the family Betaflexiviridae.

Genome organization of the $\mathrm{C} 21$ and Aze239 agents and phylogenetic relationships within the family Betaflexiviridae.

TABLE 2. List of Prunus sources found infected by Prunus virus T in the present study

\begin{tabular}{|c|c|c|c|c|}
\hline Source & Host & Cultivar $^{\mathrm{a}}$ & Country & Accession number \\
\hline $\mathrm{C} 21$ & Prunus avium & Tardiva di Roccamonfina & Italy & KF700262 (complete genome) \\
\hline Aze239 & P. domestica & na & Azerbaijan & KF700263 (complete genome) \\
\hline Aze13-38 & P. cerasifera & na & Azerbaijan & KF805860 \\
\hline Aze13-39 & P. cerasifera & na & Azerbaijan & KJ534579 \\
\hline
\end{tabular}

a na $=$ not available. 
The genome of the virus identified in the $\mathrm{C} 21$ source $(6,847 \mathrm{nt})$ has a similar size to that of the agent found in the Aze239 source $(6,835 \mathrm{nt})$ and also to the genome of PVT (6,539 nt). The two genomic sequences from Prunus spp. reveal the same genomic organization, with only three slightly overlapping open reading frames (ORFs), which is very similar to that reported for some members of the family Betaflexiviridae such as PVT (Tepovirus), ACLSV (Trichovirus), and Citrus leaf blotch virus (Citrivirus) (Fig. 1) (2,17). These ORFs, which have identical sizes in the C21 and Aze239 viruses, encode, from $5^{\prime}$ to $3^{\prime}$, an RNA-dependent RNA polymerase (replicase, 1,779 amino acids [aa]), an MP (384 aa), and the coat protein ( $\mathrm{CP} ; 222$ aa). Two noncoding regions (NCRs) were identified: the $5^{\prime}$ NCRs in C21 (59 nt) and Aze239 (47 nt) were found to be shorter than in PVT (74 nt). The presence of 13 extra nucleotides at the $5^{\prime}$ end of $\mathrm{C} 21$ genome (in comparison with Aze239) was verified by cloning and sequencing both 5' RACE amplification products. The 3' NCRs were 78 and 79 nt long in C21 and Aze239, respectively. As for other Betaflexiviridae members, this short $3^{\prime}$ NCR is followed by a polyA tail.

Phylogenetic analysis of the putative replicase encoded by the Aze239 and C21 agents and the corresponding proteins of representative members of the families Alphaflexiviridae and Betaflexiviridae showed that both viruses cluster clearly with Betaflexiviridae members (Fig. 2A). More precisely, they form a cluster with the sole member of genus Tepovirus, PVT, and this grouping is supported by a highly significant $99 \%$ bootstrap value. However, the level of amino acid identity between these proteins is very low, with only 34.1 and $34.5 \%$ between the replicase of PVT and that of C21 and Aze239, respectively (Table $3)$. Phylogenetic analyses performed for the $\mathrm{CP}$ and the MP proteins (Fig. 2B and C) show again a tendency of the two novel agents to group with PVT; however, this grouping is not supported by significant bootstrap values, probably reflecting the lower levels of amino acid identity between the proteins of PVT and those of the Aze239 and C21 agents (at best, 28.9\% amino acid identity between the CPs from PVT and Aze239). The level of nucleotide identity in the replicase genes was found to be 46.3 and $46.7 \%$ between PVT and C21 or Aze239, respectively, which is slightly higher than the genus demarcation criterion, defined as $45 \%$ nucleotide identity in the CP or replicase genes in the family Betaflexiviridae (2). In contrast, the nucleotide identity in the $\mathrm{CP}$ gene between PVT and the two new agents was found to be below this cut-off, with only 39 and $37.7 \%$, respectively.

The C21 and Aze239 agents are clearly related to each other and form a tight and $100 \%$ supported phylogenetic cluster, whatever the proteins considered (Fig. 2A to C). This close relationship between $\mathrm{C} 21$ and Aze239 viruses is reinforced by the high levels of amino acid identity found in the three encoded proteins. The amino acid identity was $78.7 \%$ in the MP $(80.1 \%$ nt identity), $79.9 \%$ in the replicase (72\% nt identity), and $89.5 \%$ in the CP (80.3\% nt identity) (Table 3). Considering the species demarcation criteria accepted in the family Betaflexiviridae (2) $(<72 \% \mathrm{nt}$ identity or $80 \%$ aa identity in the CP or polymerase), the C21 and Aze239 agents should be considered as distinct isolates from the same viral species.

Development of a molecular RT-PCR assay for the detection of the novel virus and analysis of its diversity. Based on the alignment of the full-length genome sequences of the C21 and Aze239 isolates, polyvalent primers were designed to allow the detection of this novel virus in a two-step RT-PCR reaction. The forward primer, Tep-1F, is located in the $\mathrm{CP}$ gene and was degenerate to account for the nucleotide diversity between the two isolates. The reverse primer, Tep-1R, was chosen in the conserved $3^{\prime}$ NCR. In order to evaluate the prevalence of the new agent in Prunus spp., 386 Prunus samples collected during various surveys were tested for the presence of the virus. In addition to the Aze239 and C21 samples, two additional trees were found to be infected, which corresponds to a prevalence of $1 \%$ in the sampled collection. The positive samples were two myrobolan trees ( $P$. cerasifera) originating from the same geographical region in Azerbaijan (Aze13-38 and Aze13-39) (Table 2). The comparison of the partial CP nucleotide sequences (474 nt) from the four infected samples showed the Aze13-38 isolate to be identical to Aze239 in the sequenced genome region, whereas it differed by $12.1 \%$ from the other isolate from $P$. cerasifera (Aze13-39). The nucleotide divergence in the corresponding region between the Italian isolate $(\mathrm{C} 21)$ and the three Azerbaijani isolates is 18.8\% (Aze13-38) and 20.1\% (Aze13-39 and Aze239).

\section{DISCUSSION}

As previously shown by others $(3,4,7,8,15,19,20)$, the results presented here illustrate the huge potential of NGS in virus diagnostics and discovery. In addition to several well-known fruit-tree viruses, the present study allowed the discovery of isolates of a new Prunus-infecting member of the family Betaflexiviridae in the cherry and plum samples under study. The full-length genome sequences of these two isolates were determined using a combination of NGS analysis and PCR-based targeted resequencing to fill gaps in the scaffolds assembled from the NGS data and to confirm some low coverage areas. As in previous studies $(7,15)$, this partial resequencing fully validated the initially obtained NGS data.

The molecular characterization and phylogenetic analyses showed that the two isolates identified in $P$. avium and $P$. domestica were somewhat distantly related (overall $74 \%$ nucleotide identity over the full genome) but that their amino acid identities in the $\mathrm{CP}$ and in the replicase fall within the species demarcation criteria accepted for the family Betaflexiviridae (2). As a consequence, these two isolates should be considered as belonging to the same new viral species. Pairwise amino acid sequence com-

TABLE 3. Percentage of identity between proteins encoded by the genome of the Prunus virus T (PrVT) isolate C21 and the corresponding proteins of the PrVT isolate Aze239 and of members of the family Betaflexiviridae with a 30K-type movement protein ${ }^{\mathrm{a}}$

\begin{tabular}{lccc}
\hline & \multicolumn{2}{c}{ Percent amino acid identity (size [aa]) } \\
\cline { 2 - 4 } Virus $^{\text {b }}$ & $\begin{array}{c}\text { Replicase } \\
(1,779)\end{array}$ & $\begin{array}{c}\text { Movement } \\
\text { protein }(384)\end{array}$ & $\begin{array}{c}\text { Coat protein } \\
(222)\end{array}$ \\
\hline Aze239 & $79.9(1,779)$ & $78.7(384)$ & $89.5(222)$ \\
PVT (Tepovirus) & $34.1(1,607)$ & $19.9(359)$ & $28.4(214)$ \\
GVA (Vitivirus) & $30.3(1,708)$ & $12.5(279)$ & $24.5(199)$ \\
CLBV (Citrivirus) & $28.0(1,963)$ & $15.3(363)$ & $7.2(364)$ \\
ACLSV (Trichovirus) & $26.8(1,885)$ & $16.9(461)$ & $29.6(194)$ \\
ASGV (Capillovirus) & $26.3(1,868)$ & $17.4(321)$ & $25.6(238)$ \\
AVCaV (Unassigned) & $30.9(1,679)$ & $15.5(292)$ & $20.6(221)$ \\
\hline
\end{tabular}

a Sizes in amino acids (aa) of the proteins are indicated in parentheses.

b Acronyms used: PVT = Potato virus T, GVA = Grapevine virus A, CLBV = Citrus leaf blotch virus, ACLSV = Apple chlorotic leaf spot virus, ASGV = Apple stem grooving virus, and $\mathrm{AVCaV}=$ Apricot vein clearing associated virus.

\section{Replicase protein}

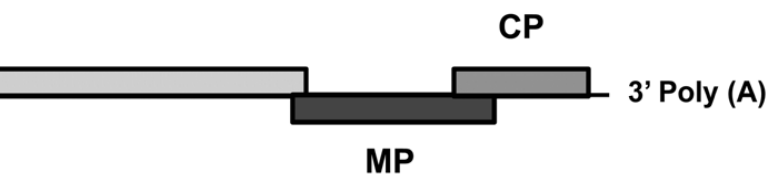

Fig. 1. Schematic representation of the Prunus virus $\mathrm{T}$ genome. $\mathrm{MP}=$ movement protein and $\mathrm{CP}=$ coat protein. 
A

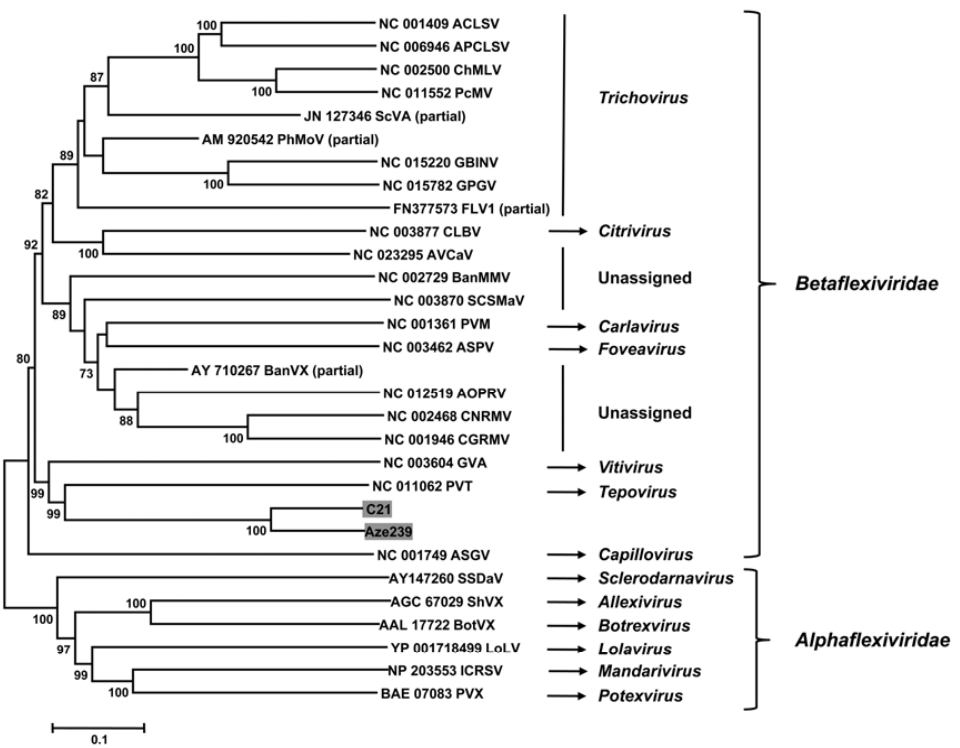

B
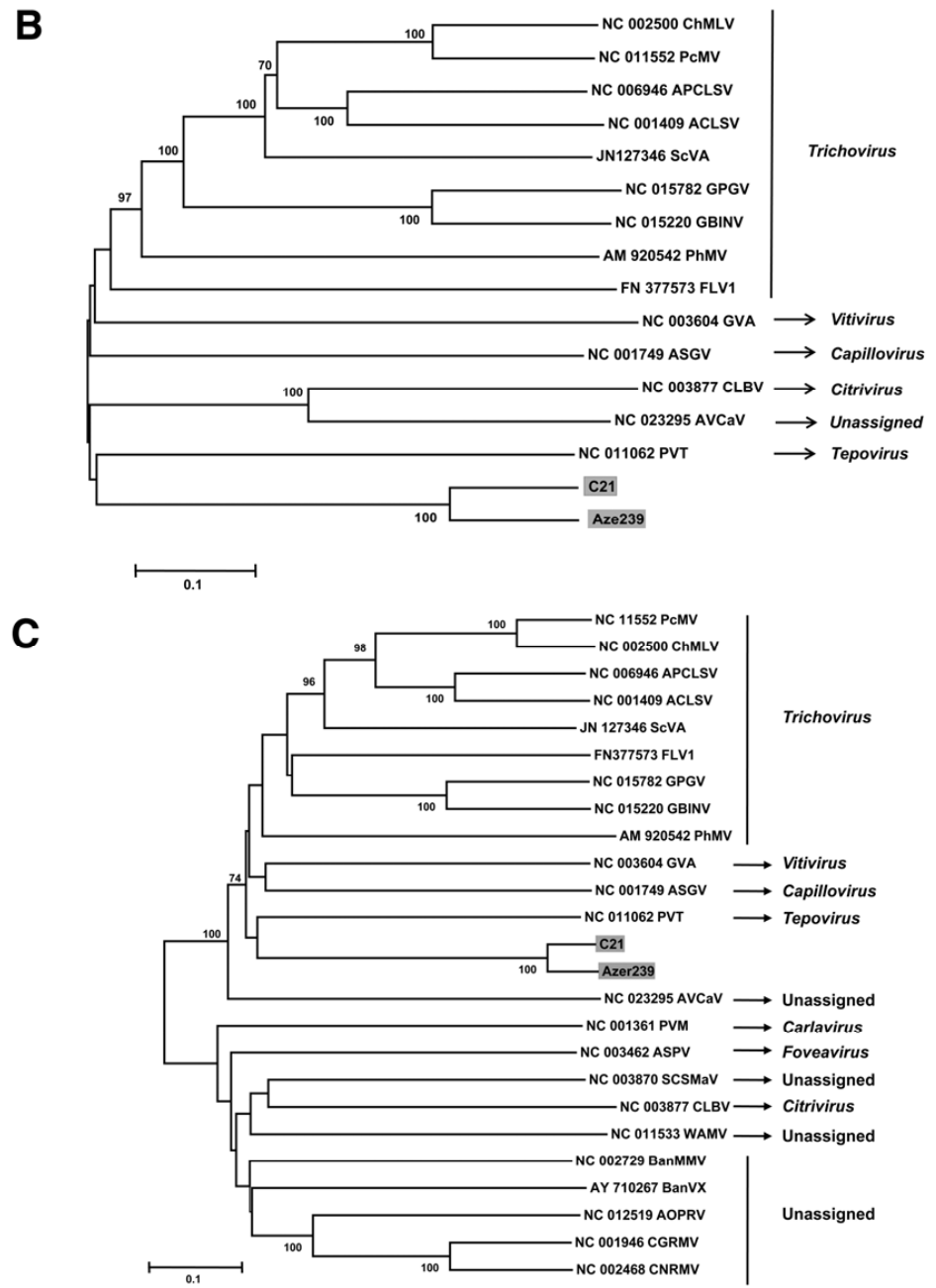

Fig. 2. Phylogenetic affinities of Prunus virus T (PrVT) within the Alpha- and Betaflexiviridae families. Unrooted phylogenetic trees were reconstructed using the deduced amino acid sequences of Aze239 and C21 PrVT isolates and those of representative members of families A, Alphaflexiviridae and A-C, Betaflexiviridae. Phylogenetic trees shown were reconstructed using $\mathbf{A}$, the replicase; $\mathbf{B}$, the movement protein; and $\mathbf{C}$, the coat protein. Trees were constructed using the neighborjoining technique in Mega 5.2, with a strict amino acid identity distance. Bootstrap values $>70 \%$ (1,000 replicates) are shown. The scale bars represent $10 \%$ divergence. When appropriate, database accession numbers are provided. Abbreviations used are ACLSV $=$ Apple chlorotic leaf spot virus, APCLSV $=$ Apricot pseudo chlorotic leaf spot virus, $\mathrm{AOPRV}=$ African oil palm ringspot virus, $\mathrm{ASGV}=$ Apple stem grooving virus, $\mathrm{ASPV}=$ Apple stem pitting virus, $\mathrm{AVCaV}=$ Apricot vein clearing associated virus, BanMMV $=$ Banana mild mosaic virus, BanVX $=$ Banana virus $X, \mathrm{BotVX}=$ Botrytis virus $X, \mathrm{CGRMV}=$ Cherry green ring mottle virus, $\mathrm{CLBV}=$ Citrus leaf blotch virus, $\mathrm{ChMV}=$ Cherry mottle leaf virus, CNRMV = Cherry necrotic rusty mottle virus, FLV1, Fig latent virus 1 , GBINV = Grapevine berry inner necrosis virus, GPGV, Grapevine pinot gris virus, GVA Grapevine virus A, ICRSV, Indian citrus ringspot virus, LoLV, Lolium latent virus, $\mathrm{PcMV}=$ Peach mottle virus, $\mathrm{PhMV}=$ Phlomis mottle virus, $\mathrm{PVM}=$ Potato virus $M, \mathrm{PVT}=$ Potato virus $T, \mathrm{PVX}$, Potato virus $X, \mathrm{SCSMaV}=$ Sugarcane striate mosaic-associated virus, $\mathrm{ScVA}=$ Scaevola virus A, ShVX = Shallot virus X, SSDaV, Sclerotinia sclerotiorum debilitation-associated RNA virus, and WAMV = White ash mosaic virus. 
parisons of each protein encoded by their genome with comparable proteins of representative members of the family Betaflexiviridae with a 30K-type MP showed that the relationships with these viruses are only very distant. However, the new virus groups consistently with PVT (genus Tepovirus) when analyzing the replicase. Highest identity levels for the $\mathrm{CP}$ and MP are also observed with PVT although, in this case, the phylogenetic grouping is not statistically supported. The currently accepted sequencebased genus discrimination criterion in the family Betaflexiviridae is identity of $>45 \%$ in the nucleotide sequences of relevant viral protein genes (replicase and CP) (2). Although a much lower value was observed in the CP gene (39\% for the Aze239 isolate compared with PVT), nucleotide identity levels higher than $45 \%$ were observed for the replicase gene between PVT and the two isolates analyzed here. Together with a similarly short genome size for the family Betaflexiviridae and the similar genomic organization, including short $5^{\prime}$ and $3^{\prime}$ NCRs, these values suggested that the new virus should be considered as belonging to the genus Tepovirus. The relatively low level of nucleotide identity observed between PVT and the new virus for the MP and CP genes fall, in fact, within the divergence range observed between various members of another Betaflexiviridae genus, Trichovirus (data not shown), further supporting this analysis. The name of PrVT is proposed for this new viral species. Although no graft transmission experiments have been performed to unambiguously demonstrate the identity of a novel transmission agent, the presence of the sequence reported here and its genetic organization and phylogenetic relationships strongly support a new Prunus-infecting viral agent. The identification of variants in four trees representing three species of Prunus further supports this idea.

The biological information concerning PrVT is still scarce. A molecular screening of $>380$ Prunus samples allowed the identification of three hosts ( $P$. domestica, $P$. avium, and $P$. cerasifera) in two countries (Italy and Azerbaijan), with an overall prevalence of $1 \%$. Due to mixed viral infections in all the trees concerned, it is difficult to associate specific symptoms with PrVT infection. Indeed, all identified host plants were simultaneously infected by well-known Prunus-infecting viruses, such as APCLSV (Trichovirus), ACLSV (Trichovirus), CVA (Capillovirus), PDV (Ilarvirus), or LChV1 (Closteroviridae). There is not information as to whether PrVT spreads in the field and, as for PVT, no vector is known (18).

The detection assay developed during the present work is based on the use of one degenerate primer designed in the $\mathrm{CP}$ gene and one primer located in the conserved $3^{\prime}$ NCR (93.6\% of identity between the Aze239 and C21 isolates). This molecular test allows the detection of relatively distant isolates of PrVT and, therefore, should be useful in the future to get a more precise vision of PrVT prevalence and geographic distribution or to try to link it to a specific symptomatology.

\section{ACKNOWLEDGMENTS}

We thank V. Decroocq and D. Tricon (INRA, Villenave d'Ornon, France) and P. Gentit and Y. Brans (Ctifl, Lanxade, France) for providing some Prunus samples; and the Platform Genotoul (INRA, Toulouse, France) for 454 pyrosequencing.

\section{LITERATURE CITED}

1. Adams, I. P., Glover, R. H., Monger, W. A., Mumford, R., Jackeviciene, E., Navalinskiene, M., Samuitiene, M., and Boonham, N. 2009. Next generation sequencing and metagenomic analysis: A universal diagnostic tool in plant virology. Mol. Plant Pathol. 10:537-545.

2. Adams, M. J., Candresse, T., Hammond, J., Kreuze, J. F., Martelli, G. P., Namba, S., Pearson, M. N., Ryu, K. H., Saldarelli, P., and Yoshikawa, N. 2012. Family Betaflexiviridae. Pages 920-941 in: Virus TaxonomyNinth Rep. Int. Committee Taxonomy of Viruses. A. M. Q. King, M. J. Adams, E. B. Carstens, and E. J. Lefkowitz, eds. Elsevier Academic
Press, London.

3. Al Rwahnih, M., Daubert, S., Golino, D., and Rowhani, A. 2009. Deep sequencing analysis of RNAs from a grapevine showing Syrah decline symptoms reveals a multiple virus infection that includes a novel virus. Virology 387:395-401.

4. Al Rwahnih, M., Daubert, S., Urbez-Torres, J. R., Cordero, F., and Rowhani, A. 2011. Deep sequencing evidence from single grapevine plants reveals a virome dominated by mycoviruses. Arch. Virol. 156:397403.

5. Al Rwahnih, M., Dave, A., Anderson, M. M., Rowhani, A., Uyemoto, J. K., and Sudarshana, M. R. 2013. Association of a DNA virus with grapevines affected by red blotch disease in California. Phytopathology 103:1069-1076.

6. Al Rwahnih, M., Dolja, V. V., Daubert, S., Koonin, E. V., and Rowhani, A. 2012. Genomic and biological analysis of Grapevine leafroll-associated virus 7 reveals a possible new genus within the family Closteroviridae. Virol. Res. 163:302-309.

7. Candresse, T., Marais, A., Faure, C., and Gentit, P. 2013. Association of Little cherry virus 1 with the Shirofugen stunt disease and characterization of the genome of a divergent LChV1 isolate. Phytopathology 103:293-298.

8. Coetzee, B., Freeborough, M.-J., Maree, H. J., Celton, J.-M., Rees, D. J. G., and Burger, J. T. 2010. Deep sequencing analysis of viruses infecting grapevines: Virome of a vineyard. Virology 400:157-163.

9. Elbeaino, T., Giampetruzzi, A., De Stradis, A., and Digiaro, M. 2014. Deep-sequencing analysis of an apricot tree with vein clearing symptoms reveals the presence of a novel betaflexivirus. Virus Res. 181:1-5.

10. Foissac, X., Svanella-Dumas, L., Gentit, P., Dulucq, M. J., Marais, A., and Candresse, T. 2005. Polyvalent degenerate oligonucleotides reverse transcription-polymerase chain reaction: A polyvalent detection and characterization tool for Trichoviruses, Capilloviruses, and Foveaviruses. Phytopathology 95:617-625.

11. Giampetruzzi, A., Roumi, V., Roberto, R., Malossini, U., Yoshikawa, N., La Notte, P., Terlizzi, F., Credi, R., and Saldarelli, P. 2012. A new grapevine virus discovered by deep sequencing of virus- and viroidderived small RNAs in cv. Pinot gris. Virus Res. 163:262-268.

12. Idris, A., Al-Saleh, M., Piatek, M. J., Al-Shahwan, I., Ali, S., and Brown, J. K. 2014. Viral metagenomics: Analysis of begomoviruses by illumina high-throughput sequencing. Viruses 12:1219-1236.

13. Ito, T., Suzaki, K., and Nakano, M. 2013. Genetic characterization of novel putative rhabdovirus and dsRNA virus from Japanese persimmon. J. Gen. Virol. 94:1917-1921.

14. Loconsole, G., Önelge, N., Potere, O., Giampetruzzi, A., Bozan, O., Satar, S., De Stradis, A., Savino, V., Yokomi, R. K., and Saponari, M. 2012. Identification and characterization of Citrus yellow vein clearing virus, a putative new member of the genus Mandarivirus. Phytopathology 102:1168-1175.

15. Marais, A., Faure, C., Couture, C., Bergey, B., Gentit, P., and Candresse, T. 2014. Characterization by deep sequencing of divergent Plum bark necrosis stem pitting virus isolates and development of a broad-spectrum PBNSPaV detection assay. Phytopathology 104:660-666.

16. Pantaleo, V., Saldarelli, P., Miozzi, L., Giampetruzzi, A., Gisel, A., Moxon, S., Dalmay, T., Bisztray, G., and Burgyan, J. 2010. Deep sequencing analysis of viral short RNAs from an infected Pinot Noir grapevine. Virology 408:49-56.

17. Rubino, L., Russo, M., De Stradis, A., and Martelli, G. P. 2012. Tepovirus, a novel genus in the family Betaflexiviridae. Arch. Virol. 157:1629-1633.

18. Salazar, L. F., and Harrison, B. D. 1978. Host range, purification and properties of potato virus T. Ann. Appl. Biol. 89:223-235.

19. Seguin, J., Rajeswaran, R., Malpica-Lopez, N., Martin, R. R., Kasschau, K., Dolja, V. V., Otten, P., Farinelli, L., and Pooggin, M. M. 2014. De novo reconstruction of consensus master genomes of plant RNA and DNA viruses from siRNAs. PLoS One 9:e88513. doi:10.1371/journal. pone.0088513

20. Studholme, D. J., Glover, R. H., and Boonham, N. 2011. Application of high-throughput DNA sequencing in phytopathology. Annu. Rev. Phytopathol. 49:14.1-14.19

21. Tamura, K., Peterson, D., Peterson, N., Stecher, G., Nei, M., and Kumar, S. 2011. MEGA5: Molecular evolutionary genetics analysis using maximum likelihood, evolutionary distance, and maximum parsimony methods. Mol. Biol. Evol. 28:2731-2739.

22. Thompson, J. D., Higgins, D. G., and Gibson, T. J. 1994. CLUSTALW: Improving the sensitivity of progressive multiple sequence alignment through sequence weighting, position-specific gap, penalties and weight matrix choice. Nucleic Acids Res. 22:4673-4680.

23. Wyant, P. S., Strohmeier, S., Schäfer, B., Krenz, B., Assunção, I. P., de Andrade Lima, G. S., and Jeske, H. 2012. Circular DNA genomics (circomics) exemplified for geminiviruses in bean crops and weeds of northeastern Brazil. Virology 427:151-157.

24. Wylie, S. J., and Jones, M. G. 2011. The complete genome sequence of a 
Passion fruit woodiness virus isolate from Australia determined using deep sequencing, and its relationship to other potyviruses. Arch. Virol. 156:479-482.

25. Wylie, S. J., Luo, H., Li, H., and Jones, M. G. 2012. Multiple polyadenylated RNA viruses detected in pooled cultivated and wild plant samples. Arch. Virol. 157:271-284.

26. Yang, X., Wang, Y., Guo, W., Xie, Y., Xie, Q., Fan, L., and Zhou, X.
2011. Characterization of small interfering RNAs derived from the Geminivirus/Betasatellite complex using deep sequencing. PLoS One 6:e16928.

27. Youssef, F., Marais, A., Faure, C., Barone, M., Gentit P., and Candresse, T. 2011. Characterization of Prunus-infecting Apricot latent virus-like Foveaviruses: Evolutionary and taxonomic implications. Virus Res. $155: 440-445$. 